\title{
Hubungan Sanitasi Lingkungan dengan Kejadian Infeksi Soil Transmitted Helminths pada Anak Sekolah Dasar di Jember
}

\section{(Association of Environmental Sanitation and Soil Transmitted Helminthes Infections among Primary School Children in Jember)}

\author{
Nur Aqmarina Kusumawardani, Erma Sulistyaningsih, Cicih Komariah \\ Fakultas Kedokteran Universitas Jember \\ Jl. Kalimantan 37 Kampus Tegalboto, Jember 68121 \\ e-mail: sulistyaningsih.fk@unej.ac.id
}

\begin{abstract}
Poor environmental sanitation is suspected to be one of the causes of soil transmitted helminthes (STH) infection. Environmental sanitation consists of water sources, latrine, sewerage, garbage disposal facilities, and floor type. The objective of this study was to investigate the relationship between environmental sanitation and the incidence of STH infection in primary school children. This was an observational analytic study with cross-sectional design. The subjects were 80 students of two elementary schools in Jember. Stool samples were collected and examined by Kato-Katz method. Data of environmental sanitation was collected by questionnaire and direct observation. Kato-Katz examination showed that 9 samples (11,3\%) infected by Ascaris lumbricoides. The majority respondents had not fulfilled requirements of good environmental sanitation. The result of Spearman test showed that there was a significant correlation between STH infection and latrine $(p=0,02)$ but there were no significant relationship between STH infection and environmental sanitation $(p=0.165)$, gender $(p=0,669)$, age $(p=$ $0,92)$, water source $(p=0.084)$, sewerage $(p=0.146)$, garbage disposal facilities $(p=0,728)$, and floor type $(p=0,065)$.
\end{abstract}

Keywords: STH infection, environmental sanitation, Primary school children

\begin{abstract}
Abstrak
Sanitasi lingkungan yang buruk merupakan salah satu faktor yang diduga menjadi penyebab infeksi Soil Transmitted Helminthes (STH). Sanitasi lingkungan terdiri dari sumber air bersih, sarana pembuangan tinja, saluran pembuangan air limbah (SPAL), sarana pembuangan sampah, dan jenis lantai rumah. Infeksi STH paling sering terjadi pada anak usia sekolah. Tujuan penelitian ini yaitu mengetahui hubungan sanitasi lingkungan dengan kejadian infeksi cacing STH pada anak sekolah dasar. Jenis penelitian adalah analisis observasional dengan desain cross-sectional yang dilakukan pada 80 siswa SDN Jubung 03 dan SDN Sukorambi 02 Jember. Pemeriksaan kejadian cacingan pada siswa dilakukan dengan pemeriksaaan feses (metode Kato-Katz). Data sanitasi lingkungan responden didapatkan dengan wawancara dan observasi rumah. Hasil pemeriksaan Kato-atz ditemukan telur Ascaris lumbricoides pada 9 sampel $(11,3 \%)$. Keadaan sanitasi lingkungan mayoritas reponden masih belum memenuhi syarat kesehatan. Hasil analisis Spearman menunjukkan terdapat hubungan yang signifikan antara kejadian infeksi STH dengan sarana pembuangan tinja dengan nilai $p=0,02$ tetapi tidak terdapat hubungan antara kejadian infeksi STH dengan sanitasi lingkungan $(p=0.165)$, jenis kelamin $(p=0,669)$, usia $(p=0,92)$, sumber air bersih $(p=0,084)$, SPAL $(p=0,146)$, sarana pembuangan sampah $(p=0,728)$, dan jenis lantai rumah $(p=0,065)$.
\end{abstract}

Kata kunci: infeksi STH, sanitasi lingkungan, Siswa Sekolah Dasar 


\section{Pendahuluan}

Penyakit cacingan atau infeksi cacing merupakan salah satu penyakit tropis terabaikan yang kejadian penyakitnya masih sering ditemukan di penduduk Indonesia. Prevalensi cacingan di beberapa kabupaten dan kota tahun 2012 menunjukkan angka lebih dari $20 \%$ dengan prevalensi jumlah daerah yang tertinggi $76,67 \%$ [1]. Survei dari Kementerian Kesehatan tahun 2013 pada anak sekolah dasar di 175 kota/kabupaten menunjukkan angka kejadian cacingan $0-85 \%$ dengan prevalensi rata-rata $28,12 \%$ [2]. Hal ini menunjukkan jumlah cacingan dari tahun ke tahun masih menunjukkan jumlah yang tinggi.

Menurut World Health Organization (WHO) pada tahun 2012 diperkirakan lebih dari 1,5 miliar orang atau sekitar $24 \%$ populasi di dunia terinfeksi cacing yang ditularkan melalui tanah. Penyakit cacingan dapat terjadi pada semua golongan umur tanpa terkecuali namun kejadian infeksi pada anak sekolah tertinggi dibandingkan golongan umur lainnya [3]. WHO menyatakan, anak usia sekolah sangat rentan terkena infeksi dari cacing tambang atau hookworm hal ini disebabkan karena kurangnya kesadaran kebersihan pribadi, belum sempurnanya sistem kekebalan tubuh, dan kebiasaan bermain tanah yang mungkin mengandung larva [4].

Faktor utama perpindahan telur cacing STH ke tubuh manusia adalah kebersihan yang buruk. Kebersihan yang dimaksud tidak hanya mengenai cara seseorang menjaga kebersihan diri, kebersihan makanan yang dikonsumsi dan juga kebersihan lingkungan tempat tinggal serta bekerja. Sanitasi yang buruk merupakan salah satu faktor penyebab penularan cacing STH. Menurut WHO, sanitasi yang buruk akan menyumbang $10 \%$ dari global burden disease [5]. Sanitasi yang baik merupakan salah satu syarat PHBS rumah tangga sehingga tercipta lingkungan yang sehat dan masyarakat yang baik.

Prevalensi kejadian infeksi cacing di Kabupaten Jember masih cukup tinggi. Berdasarkan data Dinas Kesehatan Jember tahun 2016, kasus cacingan banyak terjadi di Kecamatan Gumukmas dan Sukorambi. Persentase angka kejadian cacingan di kedua wilayah tersebut mencapai $21,5 \%$. Wilayah perkotaan selama ini dianggap sudah terbebas dari masalah cacingan, namun letak Kecamatan Sukorambi yang masih di cukup dekat dengan pusat kota Kabupaten Jember ternyata masih menjadi wilayah dengan kejadian cacingan tertinggi. Hal inilah yang mendasari penelitian ini untuk mengetahui kejadian infeksi akibat cacing STH pada anak sekolah dasar yang dihubungkan dengan keadaan sanitasi di lingkungan tempat tinggal anak.

\section{Metode Penelitian}

Jenis penelitian ini adalah crosssectional. Penelitian ini dilakukan di SDN Jubung 03, SDN Sukorambi 02, dan Laboratorium Parasitologi FK UNEJ. Penelitian dilakukan pada bulan Januari - Mei 2018 setelah mendapatkan persetujuan dari komisi etik (No. 1.147/H25.1.11/KE/2018).

Sampel pada penelitian ini ditentukan dengan metode purposive sampling. Sejumlah 80 siswa yang berasal dari SDN Jubung 03 dan SDN Sukorambi 02 dipilih berdasarkan kriteria inklusi: Siswa kelas 1 sampai kelas yang bertempat tinggal di Kecamatan Sukorambi; Siswa mendapatkan izin dari orang tua untuk menjadi responden; sampel feses diambil di rumah pada pagi hari yang telah ditentukan. Sedangkan kriteria eksklusinya adalah siswa yang tidak hadir saat pengambilan data dan data yang tidak lengkap baik spesimen feses maupun kuesioner.

Data didapatkan dengan melakukan obsevasi dan wawancara ke rumah siswa serta memeriksa sampel feses dengan metode KatoKatz. Kuesioner yang digunakan merupakan adaptasi dari "Kuesioner Kajian Perilaku Hidup Bersih dan Sehat" dari Kementerian Kesehatan RI. Analisis data untuk mengetahui hubungan antara sanitasi lingkungan dan kejadian infeksi akibat STH dilakukan menggunakan uji korelasi Spearman.

\section{Hasil}

Berdasarkan kriteria inklusi dan ekslusi penelitian diperoleh 80 siswa yang menjadi sampel penelitian, 39 siswa dari SDN Jubung 03 dan 41 siswa dari SDN Sukorambi 02. Berdasarkan jenis kelamin, sampel siswa lakilaki memiliki jumlah yang lebih banyak dibanding siswi perempuan. Distribusi jenis kelamin sampel dapat dilihat pada Tabel 1.

Jenjang kelas pada penelitian dipilih berdasarkan random sampling dan kesediaan siswa beserta orang tua untuk mengikuti penelitian. Jumlah sampel terbanyak berasal dari kelas 3 sedangkan rata-rata siswa berusia 9 tahun. 
Tabel 1. Distribusi jenis kelamin subyek penelitian.

\begin{tabular}{lcccccc}
\hline $\begin{array}{c}\text { Jenis } \\
\text { Kelamin }\end{array}$ & $\begin{array}{c}\text { SDN } \\
\text { Jubung 03 }\end{array}$ & $\begin{array}{c}\text { SDN } \\
\text { Sukorambi } \\
\text { 02 }\end{array}$ & \multicolumn{2}{c}{ Total } \\
\cline { 2 - 7 } & $\mathrm{n}$ & $\%$ & $\mathrm{n}$ & $\%$ & $\mathrm{n}$ & $\%$ \\
\hline Laki-laki & 16 & 20 & 25 & 31,25 & 41 & 51,25 \\
\hline Perempuan & 23 & 28,75 & 16 & 20 & 49 & 48,75 \\
\hline Total & 39 & 48,75 & 41 & 51,25 & 100 & 100 \\
\hline
\end{tabular}

Jenjang kelas pada penelitian dipilih berdasarkan random sampling dan kesediaan siswa beserta orang tua untuk mengikuti penelitian. Jumlah sampel terbanyak berasal dari kelas 3 sedangkan rata-rata siswa berusia 9 tahun.

Berdasarkan hasil uji kato-katz pada feses, didapatkan $11.3 \%$ (9 orang) sampel terinfeksi oleh STH. Jenis cacing yang menginfeksi siswa adalah Ascaris lumbricoides. Sembilan orang yang terkena cacingan didominasi oleh siswa kelas tiga, Siswa yang terkena infeksi STH (cacingan) rata-rata berusia delapan hingga sepuluh tahun. Jumlah siswa yang terkena cacingan lebih banyak pada siswa perempuan dibandingkan dengan siswa laki-laki. Distribusi kejadian infeksi STH berdasarkan jenjang kelas dapat dilihat pada Gambar 1.

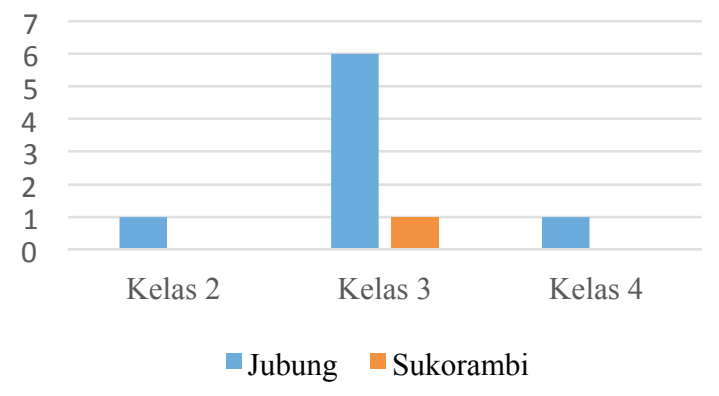

Gambar 1. Distribusi Kejadian infeksi STH berdasarkan jenjang kelas

Keadaan sanitasi rumah dapat dinilai dari sumber air bersih, kepemilikan jamban, sarana pembuangan air limbah, adanya bak sampah di rumah, serta jenis lantai rumah. Sebuah rumah dapat dikategorikan memiliki sanitasi lingkungan yang memenuhi syarat jika jumlah nilai yang diperoleh mencapai $\geq 80 \%$ dari total skor. Secara umum sarana sanitasi yang memenuhi syarat kesehatan hanya terdapat pada 13 rumah $(16,2 \%)$.

Sebagian besar responden sudah memiliki sumber air bersih baik secara pribadi maupun berkelompok. Responden yang memiliki sumber air bersih yang memenuhi syarat kesehatan bersifat pribadi sejumlah 53 responden $(66,3 \%)$.

Kebanyakan responden masih mengandalkan sungai untuk melakukan aktifitas $B A B$, responden yang tidak memiliki sarana pembuangan kotoran berupa jamban sebanyak 33 responden $(41,3 \%)$. Masyarakat yang menjadi reponden $82,5 \%$ (66 responden) lebih memilih SPAL berbentuk selokan terbuka karena dianggap lebih praktis meskipun kurang memenuhi standar kesehatan. Begitu pula dengan kepemilikan bak sampah, 51 responden tidak memiliki bak sampah sehingga sebagian besar sampah di buang ke pekarangan yang nantinya dibakar atau dipendam dalam tanah atau di buang ke saluran irigasi atau sekitar sungai. Sedangkan untuk jenis lantai rumah yang digunakan $73,8 \%$ responden menggunakan lantai ubin, keramik, atau semen. Proporsi perbandingan keadaan sanitasi dengan kejadian infeksi STH dapat dilihat pada Tabel 2.

Tabel 2. Keadaan sanitasi rumah

\begin{tabular}{|c|c|c|c|}
\hline Kategori & Kriteria & $\mathrm{N}$ & $\%$ \\
\hline \multirow{2}{*}{$\begin{array}{l}\text { Sanitasi } \\
\text { rumah }\end{array}$} & Memenuhi syarat & 13 & 16,2 \\
\hline & $\begin{array}{l}\text { Tidak memenuhi } \\
\text { syarat }\end{array}$ & 87 & 83,8 \\
\hline \multirow[t]{5}{*}{ Air bersih } & Tidak memiliki & 0 & 0 \\
\hline & $\begin{array}{l}\text { Milik bersama dan } \\
\text { tidak memenuhi } \\
\text { syarat kesehatan }\end{array}$ & 4 & 5 \\
\hline & $\begin{array}{l}\text { Milik pribadi dan tidak } \\
\text { memenuhi syarat } \\
\text { kesehatan }\end{array}$ & 8 & 10 \\
\hline & $\begin{array}{l}\text { Milik bersama dan } \\
\text { memenuhi syarat } \\
\text { kesehatan }\end{array}$ & 15 & 18,8 \\
\hline & $\begin{array}{l}\text { Milik pribadi dan } \\
\text { memenuhi syarat } \\
\text { kesehatan }\end{array}$ & 53 & 66,3 \\
\hline \multirow{5}{*}{$\begin{array}{l}\text { Sarana } \\
\text { pembuang } \\
\text { an tinja }\end{array}$} & Tidak memiliki & 33 & 41,2 \\
\hline & $\begin{array}{l}\text { Bukan berbentuk } \\
\text { leher angsa, tidak } \\
\text { memiliki tutup, } \\
\text { disalurkan ke sungai } \\
\text { atau kolam }\end{array}$ & 0 & 0 \\
\hline & $\begin{array}{l}\text { Bukan berbentuk } \\
\text { leher angsa, dengan } \\
\text { tutup / leher angsa } \\
\text { dan disalurkan ke } \\
\text { sungai }\end{array}$ & 15 & 18,8 \\
\hline & $\begin{array}{l}\text { Bukan berbentuk } \\
\text { leher angsa, dengan } \\
\text { tutup dan disalurkan } \\
\text { ke septic tank }\end{array}$ & 0 & 0 \\
\hline & Berbentuk leher & 32 & 40 \\
\hline
\end{tabular}




\begin{tabular}{|c|c|c|c|}
\hline & $\begin{array}{l}\text { angsa dan disalurkan } \\
\text { ke septic tank }\end{array}$ & & \\
\hline \multirow[t]{5}{*}{ SPAL } & Tidak memiliki & 0 & 0 \\
\hline & $\begin{array}{lr}\text { Diresapkan } & \text { dan } \\
\text { mencemari } & \text { sumber } \\
\text { air } & \\
\end{array}$ & 0 & 0 \\
\hline & $\begin{array}{l}\text { Disalurkan ke selokan } \\
\text { terbuka }\end{array}$ & 66 & 82,5 \\
\hline & $\begin{array}{l}\text { Diresapkan dan tidak } \\
\text { mencemari sumber } \\
\text { air }\end{array}$ & 0 & 0 \\
\hline & $\begin{array}{l}\text { Disalurkan ke selokan } \\
\text { tertutup }\end{array}$ & 14 & 17,5 \\
\hline \multirow{4}{*}{$\begin{array}{l}\text { Bak } \\
\text { sampah }\end{array}$} & Tidak memiliki & 51 & 63,8 \\
\hline & $\begin{array}{l}\text { Tidak kedap air dan } \\
\text { tidak memiliki tutup }\end{array}$ & 23 & 28,8 \\
\hline & $\begin{array}{l}\text { Kedap air dan tidak } \\
\text { tertutup }\end{array}$ & 0 & 0 \\
\hline & $\begin{array}{l}\text { Kedap air dan } \\
\text { memiliki tutup }\end{array}$ & 6 & 7,5 \\
\hline \multirow{3}{*}{$\begin{array}{l}\text { Lantai } \\
\text { rumah }\end{array}$} & Tanah & 5 & 6,2 \\
\hline & Plester retak & 16 & 20 \\
\hline & Plester halus/keramik & 59 & 73,8 \\
\hline
\end{tabular}

Analisis bivariat menunjukkan hasil yang signifikan antara kejadian infeksi STH dengan sarana pembuangan tinja dengan $\mathrm{p}<0,05$ yaitu 0,02 dan nilai koefisien korelasi $-0,259$ yang berarti keduanya memiliki korelasi yang lemah. Namun, uji korelasi antara infeksi STH dengan sanitasi lingkungan, jenis kelamin, usia, sumber air bersih, SPAL, bak sampah, dan jenis lantai rumah didapatkan hasil yang tidak signifikan dengan $p>0,05$. Sehingga dapat disimbulka terdapat hubungan yang bermakna antara kejadian infeksi STH dengan sarana pembuangan tinja yang digunakan oleh siswa. Data analisis bivariat tersebut dapat dilihat pada Tabel 3.

Tabel 3. Hubungan infeksi STH dengan usia, jenis kelamin, komponen sanitasi, dan sanitasi lingkungan

\begin{tabular}{lcc}
\hline \multirow{2}{*}{ Variabel } & \multicolumn{2}{c}{ Infeksi STH } \\
\cline { 2 - 3 } & $\begin{array}{c}\text { Koefisien } \\
\text { korelasi }\end{array}$ & $\begin{array}{c}\text { Sig.(2 } \\
\text { tailed) }\end{array}$ \\
\hline $\begin{array}{l}\text { Sanitasi } \\
\text { lingkungan }\end{array}$ & $-0,157$ & 0,165 \\
\hline Usia & 0,048 & 0,669 \\
\hline Jenis Kelamin & 0,11 & 0,92 \\
\hline Sumber Air & $-0,194$ & 0,084 \\
Bersih & $-0,259$ & 0,02 \\
\hline Jamban & $-0,164$ & 0,146 \\
\hline SPAL & $-0,039$ & 0,728 \\
\hline Bak Sampah & $-0,207$ & 0,065 \\
\hline Lantai Rumah & &
\end{tabular}

\section{Pembahasan}

Melalui penelitian ini diketahui masih terdapat $83,8 \%$ rumah yang belum memenuhi syarat kesehatan. Meskipun masih banyak rumah responden yang tidak memenuhi syarat kesehatan, kejadian infeksi STH yang ditemukan hanya $11,3 \%$. Hasil uji bivariat yang dilakukan juga menunjukkan nilai $p=0.165$. Hal ini menunjukkan terdapat faktor lain seperti higiene pribadi yang tidak diteliti namun memiliki pengaruh yang lebih besar terhadap kesehatan penghuni khususnya terkait penyakit cacingan.

Analisis bivariat uji koefisien korelasi Spearman, menunjukkan tidak terdapat hubungan yang signifikan antara kejadian infeksi STH dengan jenis kelamin Pada penelitian ini perbandingan antara siswa laki-laki yang terkena infeksi STH dengan siswa perempuan memiliki jumlah yang hampir sama. Penelitian sebelumnya menyatakan tidak terdapat hubungan antara kejadian cacingan yang ditularkan melalui tanah dengan jenis kelamin [6]. Kebiasaan bermain dan aktifitas sehari-hari antara anak laki-laki dan perempuan yang hampir sama dapat menjadi penyebab seluruh jenis kelamin memiliki faktor resiko yang sama untuk terkena infeksi STH.

Penelitian ini menunjukkan bahwa kejadian cacingan yang ditularkan melalui tanah banyak terjadi pada siswa kelas tiga dengan rata-rata siswa berusia 9 tahun (Gambar 1). Hasil uji bivariat didapatkan $p=0,92$ yang berarti tidak terdapat hubungan yang bermakna antara kejadian infeksi STH dengan usia siswa. Menurut teori, kejadian cacingan banyak terjadi pada anak usia yang lebih rendah namun kejadian ini juga sesuai dengan hasil penelitian yang dilakukan oleh Faridan bahwa kejadian cacingan yang ditemui paling besar terdapat pada kelompok usia 9-11 tahun[7]. Meskipun kejadian infeksi STH pada penelitian ini banyak terdapat pada siswa kelas tiga hal ini bukan merupakan patokan utama karena siswa kelas tiga merupakan sampel terbesar pada penelitian ini sebanyak sampel $35 \%$ dari total sampel.

Sumber air bersih yang digunakan oleh $66,3 \%$ responden merupakan sumber air bersih milik pribadi yang berasal dari PDAM, sumur bor, dan sumur galian. Ketiga sumber ini dapat dikatakan memenuhi syarat kesehatan karena secara fisik tidak memiliki bau dan rasa, jarak dari sumber pencemaran yang mencukupi. Lima belas persen dari responden masih menggunakan sumber air yang kurang memenuhi syarat kesehatan karena sumur yang 
digunakan terdapat retakan atau lumut, tali timba yang tergeletak di lantai, atau jarak dengan sumber pencemaran yang terlalu dekat sehingga dikhawatirkan menjadi jalan untuk sumber-sumber pencemaran masuk ke dalam air yang ditampung.

Hasil uji bivariat antara kejadian infeksi STH dengan sarana air bersih dengan menggunakan koefisien korelasi Spearman didapatkan nilai $p=0.084$. Hal ini menunjukkan tidak terdapat hubungan yang bermakna antara infeksi STH dengan sarana air bersih. Hasil ini sejalan dengan penelitian lain yang menyatakan tidak terdapat hubungan yang signifikan antara kejadian cacingan dengan sumber air [6]. Hal ini bisa disebabkan penggunaan air yang dimasak terlebih dahulu sebelum dikonsumsi dan terdapat beberapa responden yang mengambil air dari sumber mata air lain untuk dikonsumsi. Air sumur yang dimiliki oleh responden hanya digunakan untuk keperluan mandi dan mencuci.

Pada penelitian ini, $60 \%$ responden masih memiliki sarana pembuangan tinja yang belum sesuai dengan standar kesehatan, hal ini disebabkan masyarakat masih melakukan open defecation di sungai atau saluran irigasi serta mengalirkan hasil pembuangan ke sungai. Pada penelitian ini, hasil analisis bivariat menunjukkan terdapat hubungan antara kejadian infeksi STH dengan sarana pembuangan tinja karena $p$ value $=0,02$. Setiap $10 \%$ peningkatan penggunaan jamban mampu menurunkan prevalensi kejadian askariasis [8].

Hasil observasi dan wawancara, penggunaan jamban komunal cukup banyak digunakan selain melakukan open defecation di sungai serta mengalirkan hasil pembuangan ke sungai. Padahal penggunaan sanitasi yang bersifat komunal bukan merupakan peningkatan sarana sanitasi masyarakat karena kebersihan dan perawatannya yang tidak terjaga dengan baik [9]. Bahkan beberapa penelitian sebelumnya juga menjelaskan bahwa terdapat pola peningkatan resiko dari cacingan dengan penggunaan sanitasi secara bersama-sama [10].

Uji koefisien korelasi Spearman antara kejadian infeksi STH dengan SPAL didapatkan

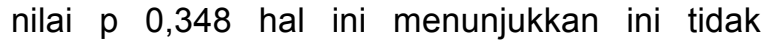
terdapat hubungan bermakna antara kejadian infeksi STH dengan SPAL. Hasil penelitian ini berbeda dengan penelitian yang dilakukan sebelumnya, yang menyatakan terdapat hubungan bermakna antara kejadian infeksi cacingan pada anak sekolah dasar dengan saluran pembuangan air rumah [11]. Sarana
SPAL yang baik tidak dapat mencemari sumber air maupun lingkungan sekitarnya. Idealnya SPAL dibuat secara tertutup dan dilakukan pengolahan sebelum akhirnya dibuang. Responden penelitian banyak mengunakan SPAL yang bersifat terbuka padahal SPAL seperti ini masih berisiko menularkan penyakit yang diakaibatkan oleh limbah buangan. Jika pada musim hujan, limbah dari SPAL terbuka bisa tergenang bersama air, apalagi tidak semua rumah responden memiliki sistem drainase sehingga air banyak tergenang secara tidak teratur. Penggunaan alas kaki dan lantai rumah yang lebih tinggi dari permukaan bisa menjadi faktor penyebab tidak terjadi infeksi STH.

Sarana pembuangan sampah yang dimiliki 28,8\% responden berupa keranjang sampah dari bambu yang tidak kedap air dan tidak memiliki tutup. Bak sampah yang tidak kedap air dapat berisiko menularkan penyakit serta tutup pada bak sampah bisa menghalau vektor penyakit seperti lalat dan tikus. Sebanyak $63,8 \%$ responden tidak memiliki bak sampah sehingga memilih membuat lubang buangan di sekitar pekarangan atau membuang di jurang sekitar sungai. Pembuatan lubang buangan sampah di pekarangan dapat dilakukan tetapi hanya digunakan untuk pembuangan sampah organik saja, saat ini lubang tersebut juga digunaan untuk membuang sampah anorganik sehingga dapat mencemari lingkungan.

Uji koefisien korelasi Spearman antara kejadian infeksi STH dengan sarana pembuangan sampah didapatkan nilai $p=0,728$ menunjukkan ini tidak terdapat hubungan bermakna antara kejadian infeksi STH dengan sarana pembuangan sampah. Hasil ini sejalan dengan penelitian pada murid sekolah dasar di Purus Padang yang menemukan tidak terdapat hubungan antara kejadian ascariasis dan tricuris dengan sarana pembuangan sampah [12]. Tidak terdapat hubungan bermakna antara kejadian cacingan dengan sarana pembuangan sampah dapat disebabkan faktor lain yang tidak diteliti seperti status gizi anak dan kebersihan pribadi.

Jenis lantai rumah dapat mempengaruhi kejadian cacingan. Telur cacing mudah melekat pada benda di tanah ataupun yang bersentuhan dengan tanah. Jenis lantai rumah yang berasal dari tanah memiliki resiko menjadi sarana penularan cacingan. Responden dari penelitian yang memiliki jenis lantai rumah berupa tanah sebanyak $6,2 \%$ sedangkan sisanya memilki jenis lantai semen, ubin, ataupun keramik. Jenis lantai semen, ubin, dan keramik dapat memutus 
siklus hidup cacing karena menghindarkan kontak langsung dengan tanah sehingga infeksi STH dapat berkurang. Hasil uji bivariat pada penelitian ini tidak terdapat hubungan antara kejadian cacingan yang ditularkan dari tanah dengan kondisi lantai rumah karena nilai $p$ yang didapat dari uji spearman sebesar 0,065. Tidak terdapat hubungan infeksi STH dengan jenis lantai tanah mungkin dipengaruhi oleh higiene pribadi. Selain itu pada responden yang rumahnya memiliki jenis lantai tanah, penggunaan alas kaki dapat menjadi faktor pencegahan kejadian cacingan. Penelitian ini sejalan dengan penelitian di Kabupaten Buton Tengah tentang kejadian askariasis dan trikuriasis dengan jenis lantai rumah siswa sekolah dasar [13].

Hasil pemeriksaan menunjukkan kejadian infeksi STH lebih banyak terjadi di Desa Jubung (delapan sampel) dibandingkan di Desa Sukorambi (satu sampel). Kesembilan dari 80 sampel mengandung telur A.lumbricoides. Hasil ini sesuai dengan penelitian Ramayanti dan Sandy yang menyatakan kejadian cacingan akibat STH banyak disebabkan oleh $A$. lumbricoides [6,14]. Selain itu, WHO menyatakan cacing jenis $A$. lumbricoides merupakan STH yang paling sering ditemukan menginfeksi manusia dan menyebabkan 60.000 kematian setiap tahunnya[15].

Kasus cacingan dapat dipolakan berdasarkan daerah munculnya kejadian. Pada kasus cacingan akibat hookworm, lebih sering ditemukan pada daerah rural. Salah satu penyebabnya adalah penggunaan night soil atau tinja yang sudah dicampurkan dengan tanah dan digunakan sebagai pupuk tanaman. Sedangkan untuk trichuriasis dapat muncul di wilayah urban maupun rural. Kejadian ascariasis lebih sering muncul pada daerah sub urban dan daerah peri urban [16]. Ascariasis yang ditemukan pada penelitian ini ditemukan pada Desa Jubung yang termasuk wilayah sub urban. Di desa Sukorambi yang termasuk wilayah rural, kejadian cacingan yang ditemukan lebih rendah.

Banyaknya kejadian cacingan di Desa Jubung dapat disebabkan sanitasi lingkungan yang kurang baik, masyarakat yang tinggal disana masih menggunakan saluran irigasi sebagai sarana cuci kakus. Sedangkan di Desa Sukorambi aliran sungai sudah jarang digunakan sebagai sarana cuci kakus karena jarak yang cukup jauh dan jalan yang curam tetapi masih banyak masyarakat yang membuang sampah di sekitaran sungai. Sumber air yang digunakan di kedua desa ini juga berbeda, rata-rata responden di Desa Sukorambi menggunakan air PDAM sedangkan di Desa Jubung masyarakat masih menggunakan air sumur baik berupa sumur galian atau sumur bor. Penggunaan sumur sebagai sumber air harus memperhatikan keadaan air yang dihasilkan baik secara fisik, kimia, dan biologis dalam air serta keadaan dari tempat penampungan air sehingga sesuai dengan standar kesehatan.

Pada penelitian ini masih terdapat banyak keterbatasan dan kekurangan. Peneliti hanya menghubungkan antara kejadian infeksi STH dengan keadaaan sanitasi lingkungan tanpa memperhatikan jumlah anggota keluarga yang tinggal dalam satu rumah, jumlah pemakaian saran sanitasi rumah, dan higien personal siswa maupun anggota keluarga yang tinggal bersama. Pemberian obat cacingan oleh Dinas Kesehatan kepada siswa dapat menjadi salah satu faktor rendahnya jumlah infeksi STH yang ditemukan. Meskipun pemberian obat cacing pada siswa SDN Jubung 03 dan SDN Sukorambi 02 dilakukan satu kali dalam setahun, namun terbukti efektif mencegah kejadian cacingan pada siswa.

\section{Simpulan dan Saran}

Angka kejadian infeksi STH pada SDN Jubung 03 dan Sukorambi 02 sebesar 11,3\% dengan jenis cacing Ascaris lumbricoides. Secara umum, kondisi sanitasi di lingkungan rumah yang dimiliki oleh masyarakat masih belum memenuhi syarat kesehatan. Infeksi STH memiliki korelasi yang signifikan dengan sarana pembuangan tinja namun pada sanitasi lingkungan, usia, jenis kelamin, sumber air bersih, SPAL, sarana pembuangan sampah, dan jenis lantai tidak memiliki hubungan yang bermakna.

Perlu diadakan sosialisasi untuk mengedukasi masyarakat terkait pentingnya ketersediaan sarana sanitasi yang bersih. Pemberian obat cacing secara rutin dan sosialisasi pentingnya mengkonsumsi obat cacing diharapkan mampu mencegah terjadinya infeksi. Edukasi mengenai bahaya cacingan sebaiknya dilakukan secara berkala kepada seluruh lapisan masyarakat.

\section{Daftar Pustaka}

[1] Direktorat Jenderal PP\&PL Kemenkes RI. Profil Pengendalian Penyakit dan Penyehatan Lingkungan Tahun 2012. Jakarta: Kementerian Kesehatan Republik 
Indonesia. 2013.

[2] Direktorat Jenderal PP\&PL Kemenkes RI. Profil Pengendalian Penyakit dan Penyehatan Lingkungan Tahun 2014. Jakarta: Kementerian Kesehatan Republik Indonesia. 2015.

[3] Direktorat Jenderal PP\&PL Kemenkes RI. Pedoman Pengendalian Kecacingan. Jakarta: Kementerian Kesehatan Republik Indonesia. 2012.

[4] Habtamu K, Abdissa B, Zeleke M. Prevalence of Necator Americanus Infection and Risk Factor Among School-Age in Mirab Abaya District, South Ethiopia. Asian Pasific Journal of Tropical Disease. 2015. 5(5): 363368.

[5] Duncan M, Jon L, Beth S, David T. Sanitation and Health. Plos Medicine. 2010. $7(11)$.

[6] Samuel S, Sri S, Soeyoko. Analisis Model Faktor Resiko yang Mempengaruhi Infeksi Kecacingan yang Ditularkan Melalui Tanah Pada Siswa Sekolah Dasar di Distrik Arso Kabupaten Keerom, Papua. Media Litbangkes. 2015. 25(1):1-14.

[7] Kharis F, Lenie M, Nelly AA. Fakor-faktor yang Berhubungan dengan Kejadian Kecacingan Pada Siswa Sekolah Dasar Negeri Cempaka 1 Kota Banjar Baru. Jurnal Buski. 2013. 4(3):121-127.

[8] Steffen AS, Petra C, Inge K, Dickens OK, et. al. Ascaris lumbricoides Infection and Its Relation to Environmental Factors in Mbeya Region of Tanzania, a Cross-Sectional, Population-Based Study. Plos One. 2014. 9(3).

[9] William EO, Aisha EPS, Michael RK, Tekola $\mathrm{E}$, et al. Association of Community Sanitation Usage with Soil-Transmitted
Helminth Infection Among School-Aged Children in Amhara Region, Ethiopia. Parasites \& Vectors. 2017. 10(91)

[10] Merieke H, Oliver C, Rachel p, Gabrielle KSC, et al. Shared Sanitation versus Individual Househols Latrines: A Systematic Review of Health Outcomes. Plos One. 2014. 9(4)

[11]Umi M. Hubungan Sanitasi Lingkungan Rumah Terhadap Kejadian Kecacingan Pada Anak Sekolah Dasar. Jurnal Kesehatan. 2017. 10(1): 32-39.

[12] Hildya K, Nuzulia I, Husnil K. Hubungan Sanitasi Lingkungan Rumah dengan Kejadian Ascariasis dan Trichuriasis pada Siswa SDN 29 Purus Padang. Jurnal Kesehatan Andalas. 2015. 4(3): 718-723.

[13] Zakia S, Lymbran T, Ainurrafiq. FaktorFaktor yang Berhubungan dengan Kejadian Kecacingan pada Siswa Sekolah Dasar Negeri 02 Mawsangka Kabupaten Buton Tengah Tahun 2017. Jurnal IImiah Mahasiswa Kesehatan Masyarakat. 2017. 2(7).

[14] Indri R. Prevalensi Infeksi Soil Transmitted Helminths pada Siswa Madrasah Ibtidaiyah Ittihadiyah Kecamatan Gandus Kota Palembang. Syifa' Medika. 2018. 8(2): 102107.

[15]WHO. Water Sanitation Hygiene: Water Related Disease. 2017. [sititasi 9 April 2018].

Dari:http://www.who.int/water_sanitation he alth/diseases-risks/diseases/ascariasis/en/.

[16] Shelby LS, Niko Y, Ana LS. The geography and scale of soil transmitted helminth infection. Springer International Publishing. 2017. 